DOI: 10.32370/IA_2021_06_15

\title{
Diagnosis of the Levels of Social Competence Among Elementary School Pupils
}

\author{
Matviienko Olena \\ Doctor of Pedagogical Sciences, Full Professor, \\ Dragomanov National Pedagogical University (Ukraine, Kyiv)
}

\author{
Hubarieva Daria \\ Postgraduate student \\ Dragomanov National Pedagogical University (Ukraine, Kyiv)
}

\begin{abstract}
The article considers the issue of social competence. The structure of social competence and the model of its measurement are offered. The authors stress that the first phase of forming the foundations of a child's social competence is his family. However, later it becomes its educational space, so the authors consider its important to measure the level of this competence during the educational process.

Presented the diagnosis of the level of social competence among elementary school pupils (7-8 years), 402 children and 16 teachers took part in the formative experiment. Based on the diagnosis Assessment of Social Competence (ASC): A scale of social competence functions (1985) (adapted to national values and the age of primary school pupils), it was found that it exceeds the initial and intermediate level of social competence with the most developed function of caring thinking. Which is natural for this age group. However, the understanding of social reality and the cessation of egocentrism showed the greatest indicators at the initial level of social competence, which indicates one of the areas of work in forming the foundations of this competence and indicates a purposeful process of education.

Key words: social competence, social flexibility, elementary school pupils, functions of social competence, components of social competence.

Актуальність дослідження. Соціальна компетентність у сучасному світі набуває своєї актуальності. Дослідження останньої епохи надають підтвердження, що розвиток соціальних навичок та гнучкості впливає на успішність особистості та стає в основу розвитку індивідууму [23]. Окремо слід зауважити, що соціальна компетентність включає в себе розвиток soft skils, що на даному етапі людства відіграють важливе значення [5, с. 10]. Адже, розвиток індивідуальних, комунікативних та управлінських навичок необхідні як для повсякденного життя, так i для роботи. Хоча, наприклад, нарциси, психопати та макіавелліанці мають у більшій мірі розвинуті комунікативні вміння, управлінські та індивідуальні, але ці особистості відомі своєю безрозсудністю та «збитим» моральним компасом [3; 17; 18]. Аналізуючи наукові дослідження можемо стверджувати, що недостатньо опановувати навички соціальної гнучкості, потрібно ще розвивати турботливе мислення, що входить до однієї з функцій соціальної компетентності. Тобто, соціальна
\end{abstract}


компетентність ширша за soft skils та спрямована на становлення всебічно-гармонійної особистості.

Зокрема, ця компетентність розвивається впродовж усього життя. Особистість опановує різноманітний соціальний досвід, який має величезний вплив на іï стосунки у соціумі та їі власне «Я». Але основний період для іiї розвинення припадає на вік молодшого школяра який задає направлення їі соціалізації в суспільстві $[4 ; 10 ; 11 ; 12 ; 25 ; 26 ; 27]$.

Мета даної статті - висвітлити авторське дослідження по рівню сформованості соціальної компетентності в учнів молодшого шкільного віку.

Виклад основного матеріалу. Проблемою розвитку соціальної компетентності займається багато вітчизняних та зарубіжних учених: А. Флієр, А. Асмолов, К. Калініна, А. Мудрик, В. Шахрай, В. Ковальчук, Л. Петько, Pamela Orpinas, Kanksha Singh, Melanie A Dirks, Miriam H. Kirmayer, Sonja Perren та ін. Однак, проаналізувавши наукові дослідження, ми дійшли висновку, що єдиної виокремленої структури соціальної компетентності в науковому обігу ще не існує.

Узагальнивши та систематизувавши опрацьований матеріал, згідно якого, соціальна компетентність включає в себе розумовий інтелект, емоційний та практичний, уможливило виділити ії компоненти: когнітивно-мотиваџійний, емоційно-рефлексивний та операційнодіяльнісний [6].

Кожний компонент виконує свої функції які тотожні деяким проявам гнучких навичок, у сумі отримуємо 9 (дев’ять) (Рис. 1).

Більш детально розглянемо функції. Функція - слідування правил. У соціальному світі існують свої домовленості які виступають, як правило регламентуючи та стають за основу у міжособистісному спілкуванні. У формуванні основ соціальної компетентності фундаментом виступають знання цих правил та норм. Наступна функція - зупинка свого егоцентризму. Феномен егоцентризму проявляється через відношення до світу тільки через суб'єктивні критерії оцінювання, які заважають об'єктивно сприймати і аналізувати точки зору інших, що вказує на низький рівень здатності до емпатії.

Роль цієї функції значна у міжособистісній комунікації, адже недостатня увага для розвитку неї призводить до прояву нарцисизму, психопатії та інших проявів аномальностей характеру. Розуміння соціальної дійсності переплітається 3 функцією зупинки егоцентризму, однак включає в себе ще об’єктивну оцінку себе в оточуючому світі 3 частинами розумного егоїзму. 
Наступний компонент соціальної компетентності - це емоційно-рефлексивний, що виконує наступні три функції: функція саморегулювання, надання позитивного зв'язку та турботливе мислення. Функція саморегулювання включає в себе розвиток контролю емоцій; ідентифікацію емоційних рядів; вміння осмислювати власну діяльність і свідомо нею

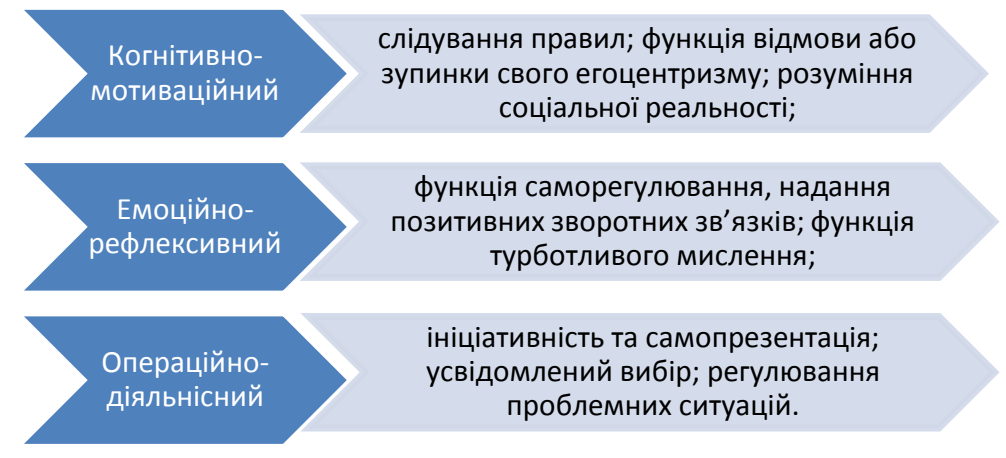

Рис. 1. Функції соціальної компетентності.

управляти, адекватно визначати і досягати цілі. Надання позитивного зв'язку - це синхронність та налаштування зі співрозмовником, вміння слухати та вміння вбачати й прислухатися до невербальних ознак особистості. Турботливе мислення включає співчуття та піклування про інших, тобто прояв турботи.

Тертій компонент соціальної компетентності - операційно-діяльнісний. Одна 3 його функцій - ініціативність та самопрезентація. Функція спонукає до розвитку та формування вмінь себе презентувати й проявляти лідерські ознаки, що відіграє важливе значення у сучасному світі. Усвідомлений вибір - функція спрямована на подолання конформізму та усвідомлене здійснення особистого вибору. Остання функція операційнодіяльнісного компоненту соціальної компетентності - це регулювання проблемних ситуацій. Вирішення проблемних ситуацій спонукає використовувати різні види мислення: творче, критичне та логічне. Замислюватись над причинністю та наслідком, досліджувати інші точки зору, вміти збирати та використовувати інформацію для вирішення конфліктних ситуацій у суспільстві. Продуктивний розвиток соціальної компетентності припадає на період молодшого шкільного віку.

Молодший шкільний вік - це період який розпочинає усвідомлений соціальний шлях особистості. Продовжується диференціація і спеціалізація нервових клітин, наростання 
обсягу горизонтально розташованих волокон і щільність капілярних мереж, ускладнюється структура відростків інтернейронів і пірамід, збільшується різноманітність нейронних ансамблів, формуються широкі горизонтальні угрупування, які включають і об'єднують вертикальні колонки. Він включає в себе продовження розвитку головного мозку, що запускає та удосконалює операції мислення: синтез, аналіз, порівняння, узгодження тощо. Тобто, у дитини починає відбуватися усвідомлене засвоєння інформації з ускладненими варіаціями ії використання.

У середньому дитинстві мозок знаходиться в постійному стані гіперактивності: мієлінізація відбувається в межах мозолистого тіла та підкіркових ділянок, що забезпечує збільшення швидкості провідності та синаптичної передачі між правою та лівою півкулею, тоді як в той же час коркова сіра речовина активно адаптується. 3 кожним роком синаптична обрізка у мозковій діяльності все більше усуває зайві синапси, тим самим регіонально розкриває потенціал особистості [9]. Стимулюючи роботу мозку у напрямі розвитку соціальної компетентності в цей період, ми надаємо досвід взаємодії особистості 3 оточуючим середовищем і закладаємо фундамент у прояві ії соціальних навичок. Якщо акцент зробити не на ті соціальні прояви отримаємо деструктивну та асоціальну поведінку в підлітковому та старшому

віці [33].

Розширюючи свої соціальні зв'язки з оточуючим світом, дитина опановує соціальні стратегії, поведінкові тактики, тим самим розвиваючи в собі соціальну гнучкість. Розвиток соціальної компетентності у цьому віці потребує особливої уваги. Дослідження вчених демонструють, що у період дитинства закладаються соціальні характеристики, які мають вплив на майбутню поведінку особистості, на іiї самоусвідомлення та прояв емпатії [7; 20; 29; 34], але деякі з впливів можуть бути незворотними [32].

Відповідно до визначених критеріїв і показників соціальної компетентності молодших школярів було підібрано комплекс діагностичних методик: методика Assessment of Social Competence (ASC): A scale of social competence functions (1985) (адаптована під вітчизняні цінності та вік молодшого школяра); експертна оцінка 3 метою підвищення рівня достовірності результатів отриманих в процесі спостереження. У дослідженні застосовано методи математичної статистики, а саме: критерій Шапіро-Уїлка, призначений для перевірки розподілення на відмінність від нормального; для розрахунку кореляцій було обрано непараметричний коефіцієнт Спірмена; для розрахунку розбіжностей між двома 
незалежними вибірками використовується непараметричний U - критерій Мана-Уїтні, між залежними вибірками непараметричний Т - критерий Уилкоксона.

Дослідно-експериментальна робота щодо розвитку соціальної компетентності молодших школярів проводилась протягом 2017-2020 років, на базі 6 шкіл. До складу експериментальної групи увійшли 200 молодших школярів другого року навчання. До складу контрольної групи увійшли 202 молодших школяра другого року навчання. Всього у формувальному експерименті прийняли участь 402 молодших школяра та 16 вчителів.

Results (Результати). Результати рівня соціальної компетентності молодших школярів за трьома основними компонентами (когнітивно-мотиваційним;емоційнорефлексивним;операційно-діяльнісним) отримані за допомогою методики Assessment of Social Competence (ASC): A scale of social competence functions (1985). Згідно діагностиці (ASC), вимір відбувається 11 функцій соціальної компетентності, проте, дана діагностика була адаптована під вітчизняну ментальність та адаптована під 9 функцій соціальної компетентності. Результати виміру кожної функції надаємо нижче.

Функція - слідування правилам. На рис. 2. графічно представлено результати вивчення особливостей усвідомлення молодшими школярами соціальних норм, правил та моральних цінностей.

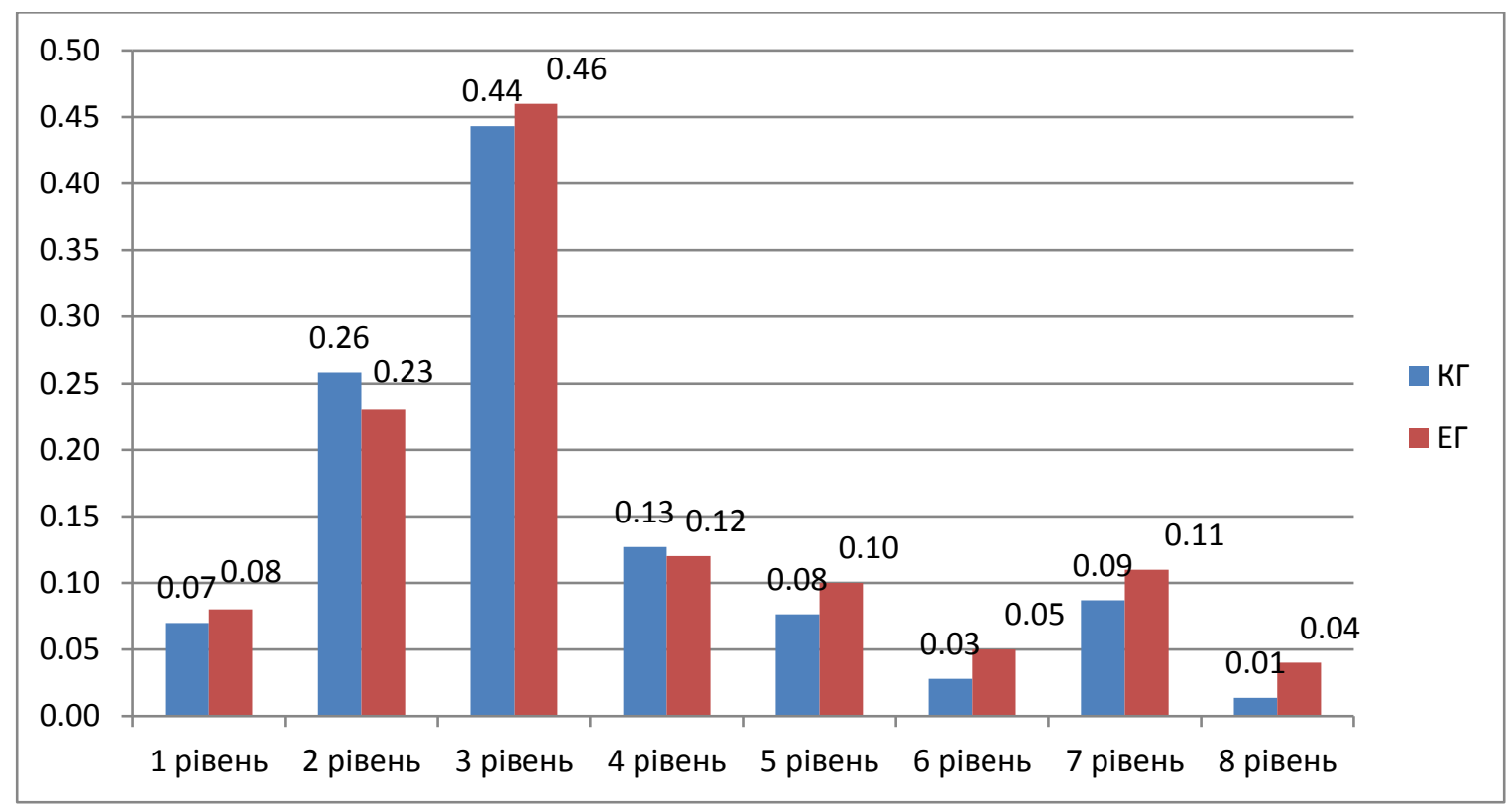

Рис. 2. Результати вивчення особливостей усвідомлення молодшими школярами соціальних норм, правил та моральних цінностей (Хср.).

Аналіз отриманих результатів дозволяє зробити наступні висновки: у молодших школярів другого року навчання переважає третій (Хср.=0,44 КГ; 0,46 ЕГ) та другий рівні 
(Хср.=0,26 КГ; 0,23 ЕГ). Однак, найменше в групах молодших школярів другого року навчання виражені восьмий $($ Хср. $=0,01$ КГ; 0,04 ЕГ) та шостий рівні $($ Хcp. $=0,03$ КГ; 0,05 ЕГ) усвідомлення соціальних норм, правил та моральних цінностей. Це свідчить, що дана функція сформована нижче середнього рівня.

Більшість молодших школярів розуміють загальні правила та норми поведінки, однак інколи порушують їх, керуючись внутрішніми бажаннями, егоцентризмом або наслідуванням нестандартної поведінки інших. Окремо слід зауважити той факт, що усвідомленого наслідування правил поведінки простежується відносно мало серед молодших школярів, що вказує на несформованість мозкових мереж, які причетні до когнітивного контролю та соціального пізнання, що, в свою чергою, сприяють змінам у розвитку соціальної поведінки $[1 ; 2]$.

На рис. 3 графічно представлені результати вивчення особливостей відмови або зупинки егоцентризму молодшого школяра. Тестування другої функції (відмови або зупинки егоцентризму) продемонструвало, що спостерігається достатня вираженість другого $(X с p .=0,31$ КГ; 0,29 ЕГ) та

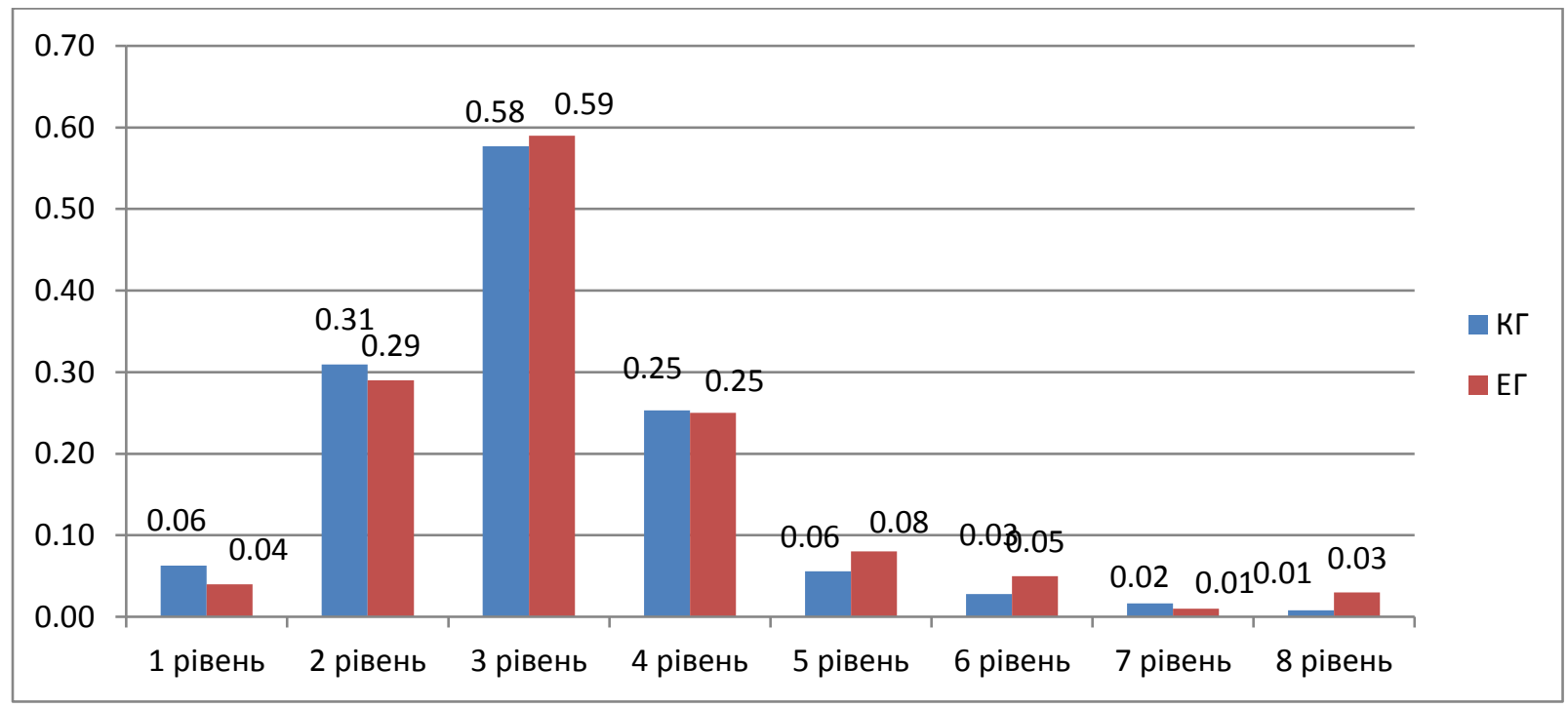

Рис. 3. Результати вивчення рівня сформованості у молодших школярів функції відмови або зупинки свого егоцентризму (Хср.).

четвертого рівнів (Хср.=0,25 КГ; 0,25 ЕГ), так школярі другого рівня характеризуються тим, що не розуміють, що існує ще одна точка зору та сторонні відчуття. Хоча існують дослідження, які вказують, що основний етап егоцентризму припадає на вік з 2 років до 7, а пізніше стихає, та надається пріоритетність соціальним нормам. Однак існують дослідження 
які вказують, що якщо був зроблений неправильний акцент у вихованні, що спотворив внутрішнє самоусвідомлення та усвідомлення інших, то це призводить до патологічних психічних проблем особистості [31].

Школярі другого року навчання з вираженим четвертим рівнем більше орієнтуються в ситуації и в першу чергу приділяють увагу не своїм імпульсам, а ситуації в якій він знаходиться, наприклад: чекає, поки діяльність завершиться, перш ніж сигналізувати про намір піти, використовуючи неформальні жести, пов'язані з конкретною діяльністю.

Проте, високий рівень розвитку функції відмови або зупинки свого егоцентризму, практично не спостерігається в досліджуваних групах: сьомий (Xcp. $=0,02$ КГ; 0,01 ЕГ) та восьмий $(\mathrm{Xcp} .=0,01$ КГ; 0,03 ЕГ) рівні. На цих рівнях респонденти володіють уміннями домовлятися про нові умови щодо ролі в діяльності та завданнях враховуючи точку зору інших, вести діалог про негативні та позитивні стосунки, включаючи розуміння соціальних ролей та рішення про припинення відносин.

На рис. 4 ми можемо бачити наскільки молодші школярі другого року навчання розуміють соціальну реальність, яка їх оточує та можуть ії оцінити, так серед респондентів переважає третій рівень (Хср.=0,46 КГ; 0,49 ЕГ), що характеризується спотворенням соціальної дійсності, неточним та обмеженим розумінням оточуючого соціуму.

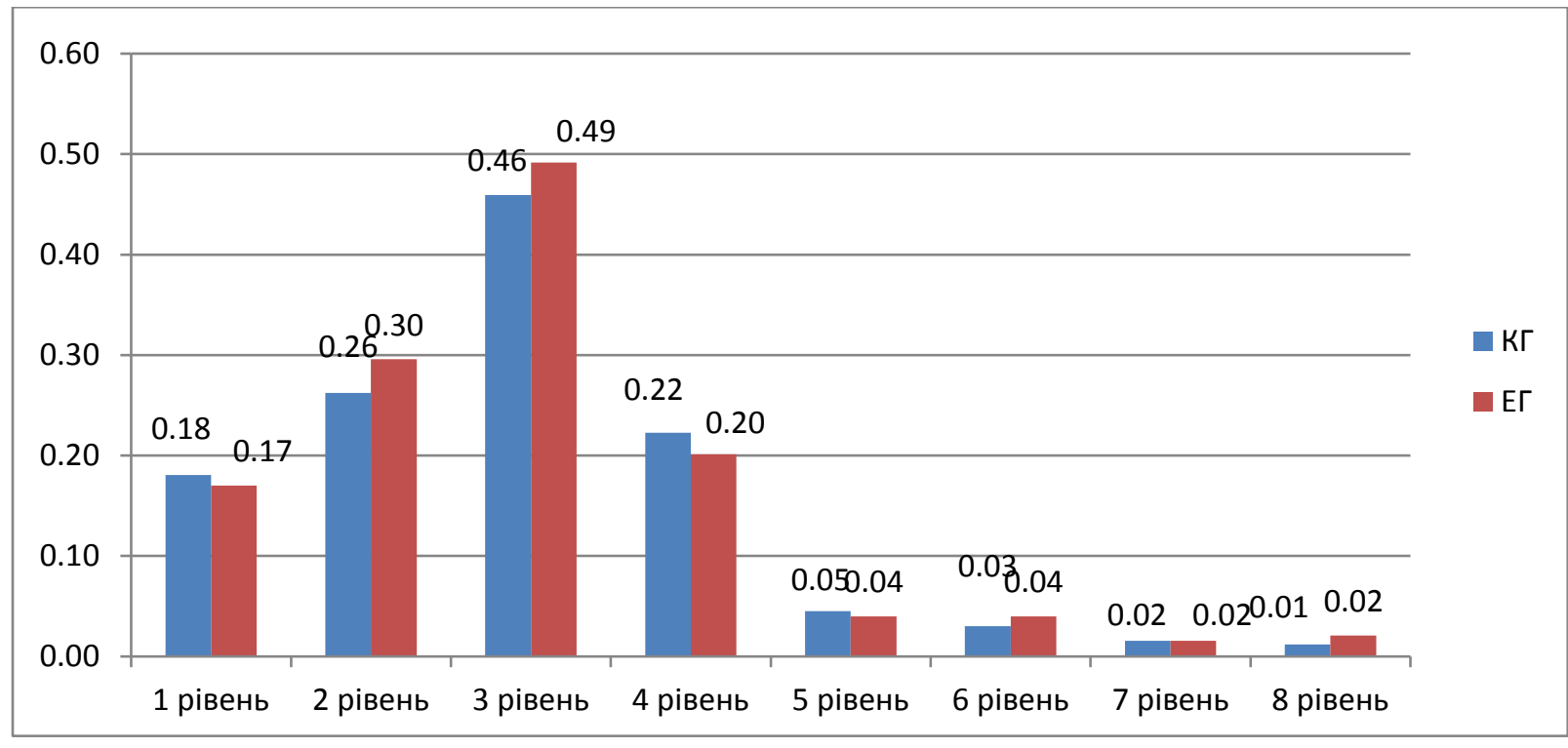

Рис. 4. Результати вивчення особливостей розуміння молодшими школярами соціальної реальності (Хср.). 
Слід зазначити, що спостерігається значне зниження до сьомого (Xсp. $=0,02$ КГ; 0,02 ЕГ) та восьмого рівнів (Хcp.=0,01 КГ; 0,02 ЕГ), що відповідають високим показникам розуміння оточуючого соціуму та вмінням орієнтуватись у ньому.

На рис. 5 графічно представлені результати вивчення рівня сформованості функції саморегулювання у молодших школярів другого року навчання.

Аналіз представлених на рис. 4. результатів дослідження дозволяє констатувати, що у обох груп переважають перший (Хср.=0,33 КГ; 0,33 ЕГ), другий (Хср.=0,39 КГ; 0,37 ЕГ) та третій (Хср.=0,35 КГ; 0,33 ЕГ) рівні сформованості функції саморегуляції, тобто молодші школярі характеризуються

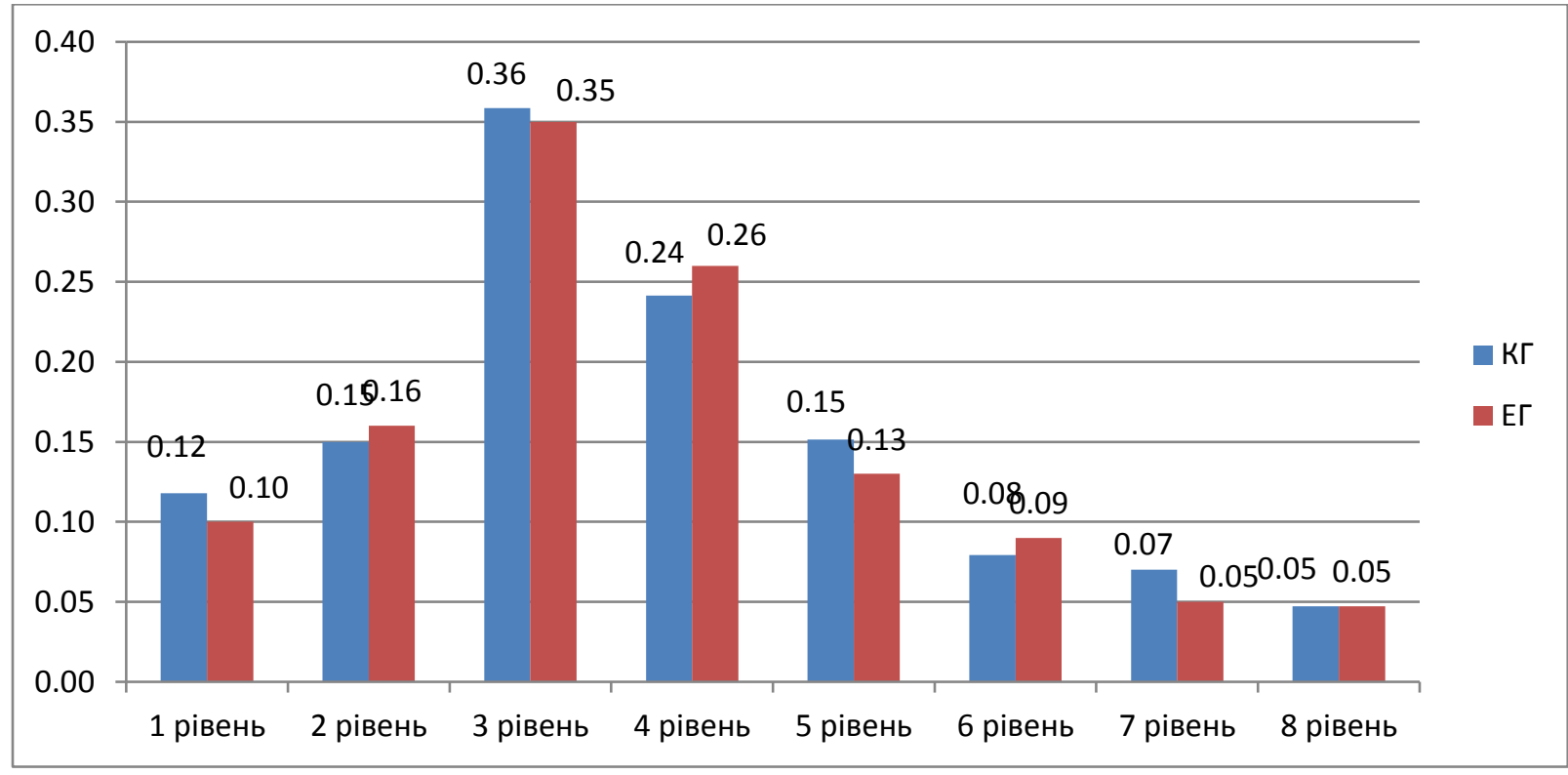

Рис. 5. Результати вивчення навичок самоконтролю та саморегуляції особистісних почуттів у молодших школярів (Хср.).

низьким рівнем сформованості самоконтролю та саморегуляції особистісних почуттів, що проявляється у припинені недоробленої запропонованої роботи, намаганні скоріше закінчити, не звертаючи уваги на результат, дії без роздумів, з ходу, не аналізуючи помилок і невдач, потребує підказки, схвалення, заохочення дорослого; до зауважень вчителя часто не прислухається; у відповіді на подразники загальним чином; використовуванні специфічної поведінки в комунікації з людиною чи перебуваючи в некомфортній ситуації, щоб повернутися до більш комфортного стану; модифікує поведінку, що сприймається, на основі негайного зворотного зв'язку. 
Високий рівень саморегуляції проявляється в доведені справи до кінця, досягненні намічених результатів, обміркованому плануванні справ і вчинків, у вмінні розраховувати свої сили, справлятися з труднощами, прояві терпеливості, вмінні приборкати як негативні, так і позитивні емоції в недоречній ситуації (Pessoa, Luiz, 2017; Ochsner, Kevin \& Gross, James, 2005). Слід зазначити, що високий рівень саморегуляції у молодших школярів другого року навчання практично не проявляється: сьомий рівень (Хср. $=0,01$ КГ; 0,02 ЕГ), восьмий (Хср.=0,01 КГ; 0,01 ЕГ). Рівень саморегуляції - динамічне утворення, залежить також від анатомічного дозрівання мозкової активності i розвитку навичок самоконтролю, що удосконалюються у ході отримання досвіду.

Вимір наступної функції, а саме - надання позитивного зворотного зв'язку у молодших школярів, графічно представлено на рис. 6, дозволяє нам зробити висновок, що у молодших школярів переважає третій рівень (Хср.=0,36 КГ; 0,35 ЕГ) розвитку функції умінь надавати позитивний зв'язок, що проявляється наступним чином: позитивний вплив спрямовують на певних важливих людей, але не на незнайомців: як правило, школярі виявляють позитивне ставлення до знайомих людей, але не підходять до когось нового або незнайомого (наприклад, викладач-замінник чи нова няня); не посміхається незнайомцеві, якщо ця особа не посміхнеться першою, не розуміє невербальних символів іншої людини, не проявляє емпатійний зв'язок.

На рис. 6 ми можемо спостерігати, що серед респондентів обох груп 6, 7, 8 рівень (високий) досить низько виражений $($ Хср. $=0,08$ КГ; 0,09 ЕГ; Хср. $=0,07$ КГ; 0,05 ЕГ; Хср. $=0,05$ КГ; 0,05 ЕГ), що проявляється у відсутності вміння слухати особистість яка не зацікавила суб'єкта, характеристика цього рівня говорить, що суб'єкт розуміє ситуації та проявляє уміння належним чином варіювати позитивний вплив для різних людей та оточення або ситуації.

На рис. 7 графічно представлені результати вивчення рівня сформованості функції турботливого мислення у молодших школярів другого року навчання. Аналіз отриманих даних дозволяє зробити наступні висновки: серед молодших школярів обох груп переважають другокласники з третім рівнем (Хср.=0,40 КГ; 0,43 ЕГ) функції турботливого мислення, що характеризується ситуативністю та нестійкістю, не усвідомленням мотивів своєї поведінки.

Як, видно на рис. 7 серед молодших школярів другого року навчання практично не виявлено прояву крайніх полярних рівнів першого (Хср. $=0,04$ КГ; 0,04 ЕГ) та восьмого 
(Хср.=0,02 КГ; 0,02 ЕГ), що 3 одного полюсу характеризується не сформованістю турботливого мислення, що проявляється в

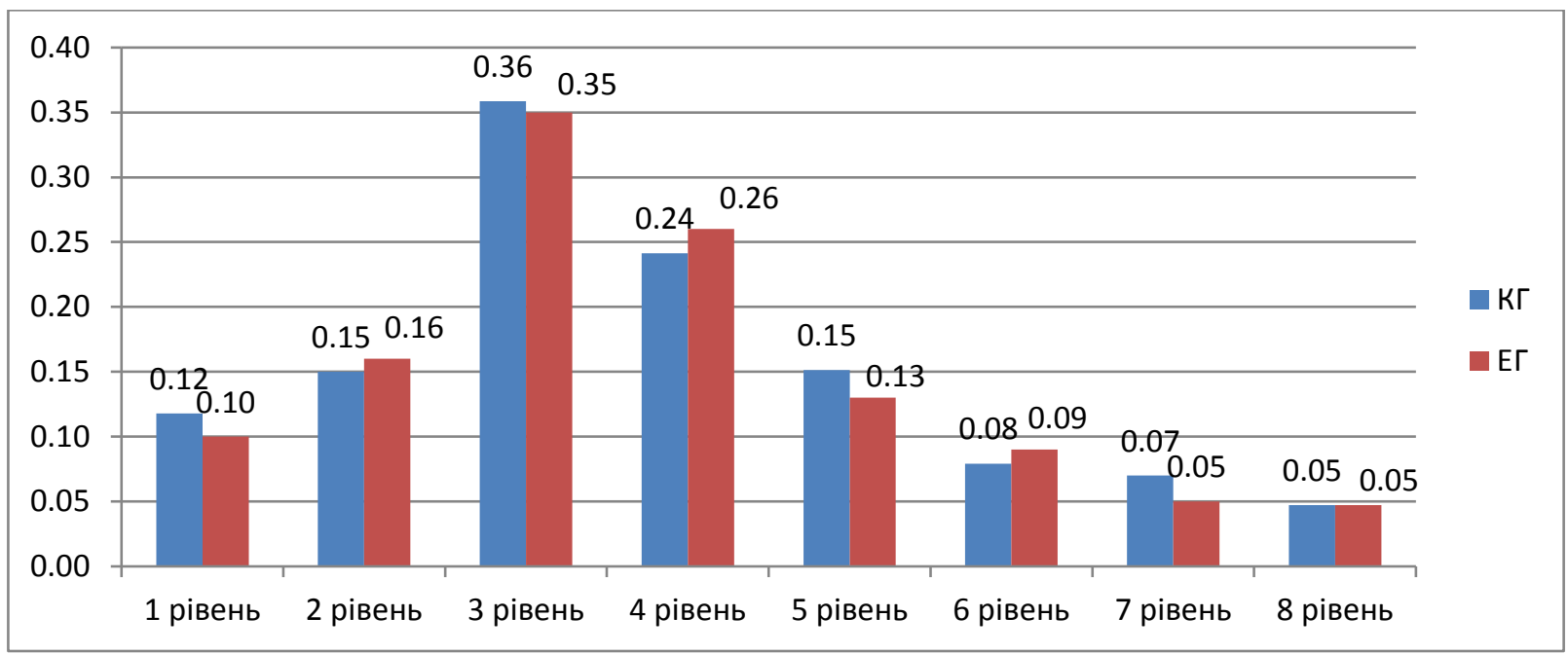

Рис. 6. Результати вивчення умінь надавати позитивні зворотні зв’язки у молодших школярів (Xсp.).

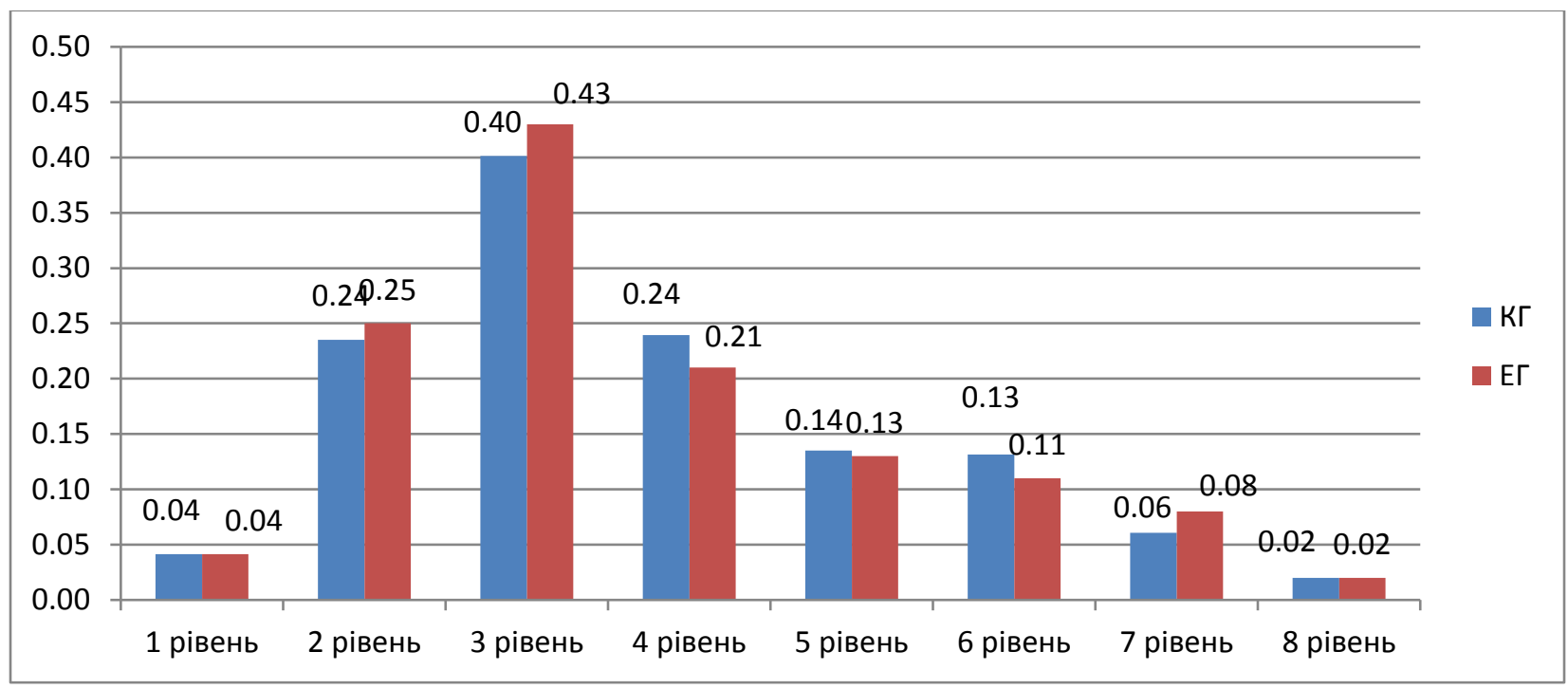

Рис. 7. Результати вивчення рівня сформованості турботливого мислення у молодших школярів (Хср.).

недоречності прояву турботи або навпаки не прийняття до уваги іншої людини та іï можливих переживань. Та, з іншого полюсу високий рівень сформованості турботливого мислення, що проявляється у пропонуванні допомоги батькам, друзям; ініціюванні бесіди, щоб задовольнити очікувану потребу в допомозі; зацікавленості у емоційних станах близьких та спробах їх розрядити. 
Саме дослідження Sandy Overgaauw (2017) [22], продемонструвало, що більш високий рівень турботливого мислення виявляється у дітей, які переживали ті самі негативні емоції, що й об’єкт до якого направлене турботливе мислення. Однак позитивні стосунки між розумінням інших, емоції та намір втішити знову були лише значущими у хлопчиків. Цей результат свідчить, що готовність допомогти іншим є основною причиною для хлопців у спілкуванні 3 іншими, тоді як дівчата прислухаються до чужих емоцій, не відчуваючи бажання підтримати та допомогти. Тобто, з цього дослідження можемо зробити висновки, що дівчата добре «зчитують» інші емоції та розуміють їх, але не намагаються допомогти. Проте, хлопці проявляють бажання допомогти, не розуміючи емоційної складової свого партнера. Це розглянемо більш детально у майбутньому дослідженні.

Наступний аналіз результатів вивчення рівня сформованості функції ініціативності ma caмопрезентації у молодших школярів, графічно представлено на рис.8, дозволив зробити висновок про те, що у респондентів переважає третій рівень (Хср. $=0,46$ КГ; 0,50 ЕГ), який проявляється в використанні загальних привітань та ініціацій молодшими школярами. Наприклад, привітає іншу особу, але може повторити те ж привітання через кілька хвилин; вітає однолітків, що зайняті діяльністю, але приєднується лише за запрошенням; ініціює рукостискання, незалежно від того, доречно це чи ні. Високий рівень сформованості ініціативності та самопрезентації у молодших школярів практично у даній вибірці не спостерігається: сьомий (Хср.=0,07 КГ; 0,07 ЕГ) та восьмий рівні (Хср. $=0,02$ КГ; 0,01 ЕГ).

Функція усвідомленого вибору. На рис. 9 спостерігається вираженість у молодших школярів другого року навчання другого (Хср. $=0,32$ КГ; 0,35 ЕГ) та третього (Хср. $=0,42$ КГ; 0,44 ЕГ) рівнів прояву усвідомленого вибору, тобто респонденти в ситуаціях вибору поводяться по-різному: залежно від того, що представлено, наприклад, дозволяють людям допомагати в одних речах, але не в інших; погоджуються їсти одні продукти, але не інші; займаються більш стереотипною поведінкою 3 певними предметами, ніж 3 іншими, наприклад, приймають рішення яке підтримує більшість; присутній страх особистого «ні» або «незадоволення».

Також може проявлятись активність у виборі, наприклад, по можливості намагається знайти певні предмети, які були прибрані, але за умови позитивного настрою; часто обирає улюблений предмет (наприклад, дістає ту саму сорочку); шукає улюблену людину в кімнаті; 
боїться нових місць.

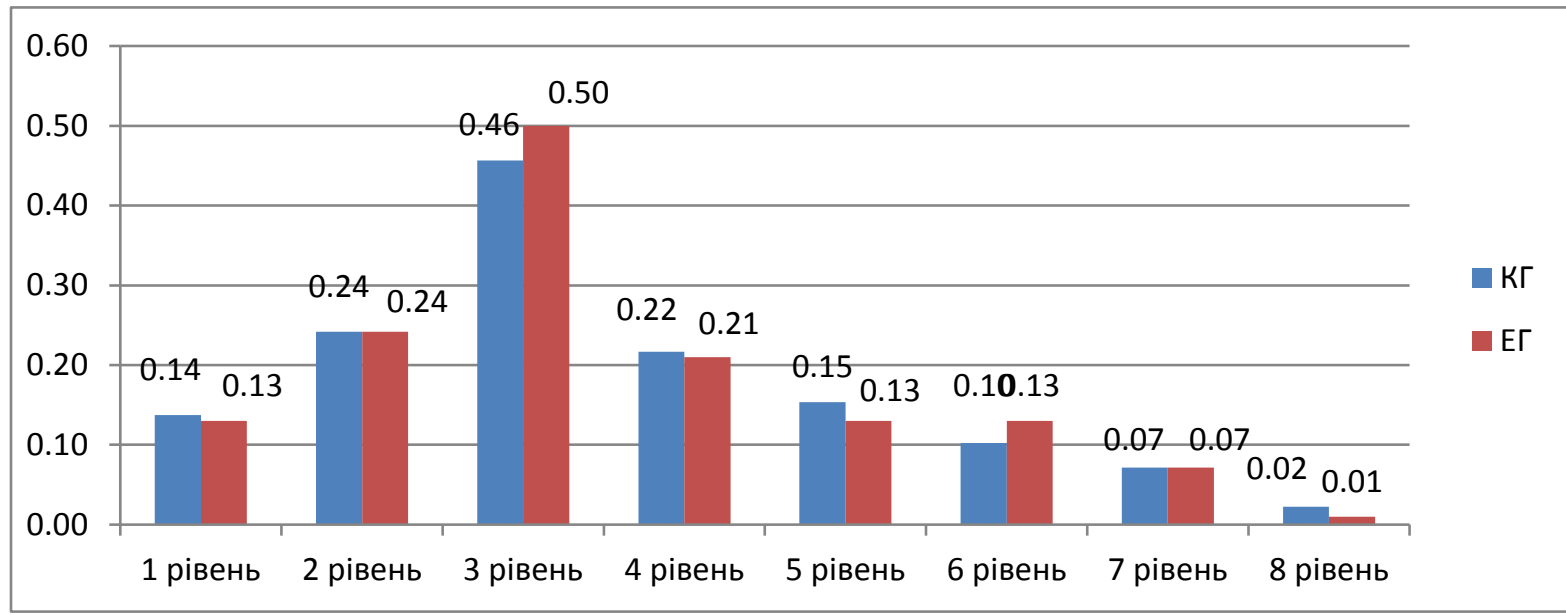

Рис. 8. Результати вивчення рівня сформованості ініціативності та самопрезентації у молодших школярів (Хср.).

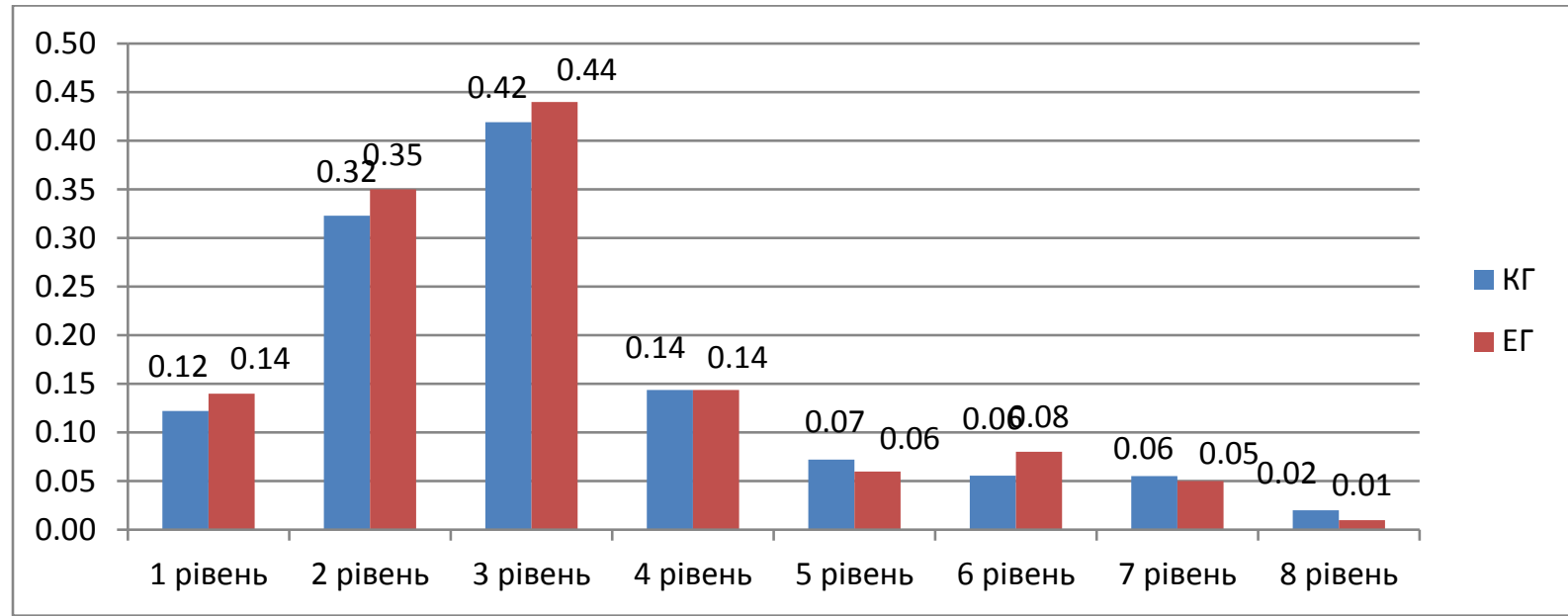

Рис. 9. Результати вивчення прояву усвідомленого вибору у молодших школярів (Хср.).

Високий рівень сформованості усвідомленого вибору у молодших школярів практично не виявлено: сьомий $(\mathrm{Xcp.}=0,06$ КГ; 0,05 ЕГ) та восьмий рівні $(\mathrm{Xcp}=0,02 \mathrm{KГ} ; 0,01$ ЕГ). Діти молодшого шкільного віку в більшій мірі ще перебувають під авторитетністю дорослих, ровесників, хоча існують феномени, коли дітлахи спокійно висловлюють свою точку зору, розуміють свої почуття та розпізнають почуття інших, що вказує на високий рівень даної функції.

На рис. 10 графічно представлено результати вивчення особливостей регулювання проблемних ситуацій у молодших школярів, аналіз отриманих даних дозволяє зробити висновок, що серед респондентів обох груп найбільш виражений третій (Хcp.=0,42 КГ; 0,43 ЕГ) та другий (Хср.=0,33 КГ; 0,35 ЕГ) рівні. При потраплянні до негативної ситуації 
респонденти з вираженістю даного рівня, діти припиняють діяльність та чекають поки хтось інший знайде вихід із ситуації що склалася. Наприклад, коли кажуть, що відповідь неправильна, учень чекає, поки хтось дасть правильну відповідь; коли його виправляють під час переходу вулиці, він більше не намагається переходити без правил і може триматись за дорослого під час очікування дозволу світлофора; не прибирає за собою, поки йому не вкажуть; у проблемних ситуаціях мають місце сльози.

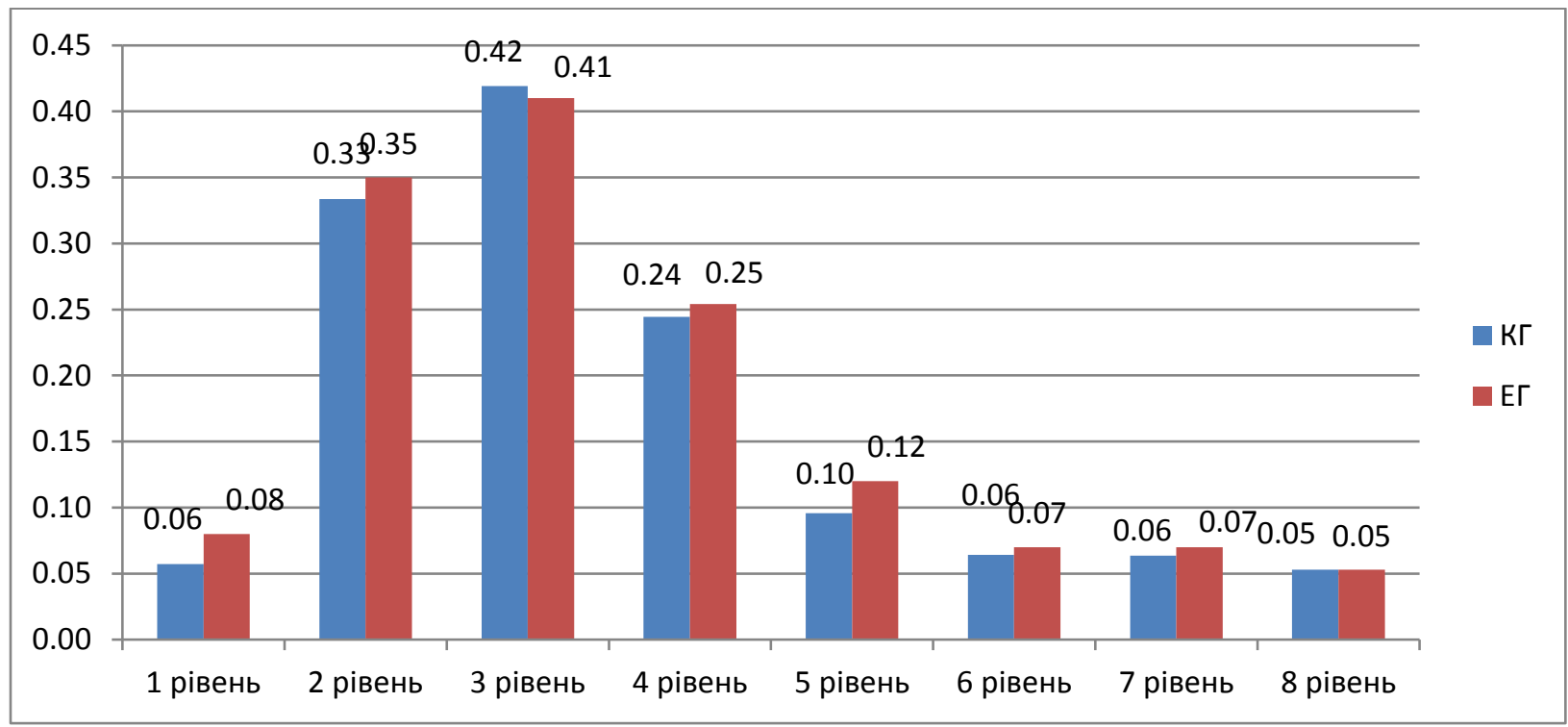

Рис. 10. Результати вивчення особливостей регулювання проблемних ситуацій у молодших школярів (Хср.).

Висновки. Представлене дослідження зассвідчило, що у дітей молодшого шкільного віку, рівень соціальної компетентності знаходиться між початковим та середнім рівнем. Зрозуміло, що з віком все більше активується та розвивається соціальний інтелект. Тому, ми можемо створювати програми для розвитку соціальної компетентності, яка буде включати рівномірний розвиток всіх функцій відповідно до вікової періодизації.

Крім того, рівень соціальної компетентності пов'язаний з академічною успішністю (Ma HK, Shek DT, Cheung PC, Lee RY, 1996). Wentzel (1991) виявив, що діти, які мали авторитет серед однолітків і демонстрували просоціальну і відповідальну поведінку, зазвичай мають високі академічні успіхі, або вважають себе більш щасливими (Ryan, Deci, 2001).

Однак, якщо існують проблеми у рівнях сформованості соціальної компетентності, то виникає ряд психічних проблем, таких як: СДУГ, тривожність, агресивність, психопатія, нарцисизм, віктимність тощо. 
Таким чином, соціальна компетентність займає особливе місце у розвитку та становленні особистості. I, акцентуючи увагу на їі розвитку у віковій групі молодшого школяра, ми уникаємо ряд проблемних ситуацій у майбутньому житті особистості. Через що, необхідно продовжити досліджувати дану проблему та розробити інструментарії для розвитку соціальної компетентності у дітей молодшого шкільного віку.

\section{References}

1. Blakemore S. J. The social brain in adolescence. Nat Rev Neurosci. 2008. 9:267-277.

2. Crone E. A, Dahl R. E. Understanding adolescence as a period of social-affective engagement and goal flexibility. Nat Rev Neurosci. 2012. 13:636-650.

3. Davis M. H., Kraus L. A, Capobianco S. Age Differences in Responses to Conflict in the Workplace. The International Journal of Aging and Human Development. 2009. 68(4):339-355. doi:10.2190/AG.68.4.d

4. Didur N., Matviienko O. The modern condition of forming sociocultural competence in future elementary school teachers. Intellectual Archive. Toronto : Shiny Word. Corp. (Canada), 2017. Vol. 6. No. 6. Pp. 103-112.

5. Gubareva D.V Social competence in the modern primary school of Ukraine. Bulletin of Alfred Nobel University. ISSN 2522-9133 (online) Series "Pedagogy and Psychology". Pedagogical sciences. 2020. № 1 (19). C. 27-32.

6. Hubarieva, D. V. Formed Social Competence as Means to Solve Bullying at Schools. 2019.

7. Linkiewich D, Martinovich V. V, Rinaldi C. M, Howe N, Gokiert R. Parental autonomy support in relation to preschool aged children's behavior: Examining positive guidance, negative control, and responsiveness. Clinical Child Psychology and Psychiatry. March 2021. doi:10.1177/1359104521999762

8. Ma H. K, Shek D. T, Cheung P. C, Lee R. Y. The relation of prosocial and antisocial behavior to personality and peer relationships of Hong Kong Chinese adolescents. The Journal of Genetic Psychology. 1996;157(3):255-266.

9. Mah V. K, Ford-Jones E. L. Spotlight on middle childhood: Rejuvenating the 'forgotten years'. Paediatr Child Health. 2012; 17(2):81-83. doi:10.1093/pch/17.2.81

10. Matviienko Olena. Features charity education in primary school children / Olena Matviienko // Prospects for development of education and science: Collection of scientific articles. - Academic Publishing House of the Agricultural University Plovdiv, Bulgaria, 2016. - P. 326-329.

11. Matviienko O. Integration of fundamental and practical training future primary school teacher in the context of a new Ukrainian school development / O. Matviienko // Perspectives of research and development : Collection of scientific articles. - SAUL Publishing Ltd, Dublin, Ireland, 2017. - P. 147-150.

12. Matviienko O. Pedagogy of partnership in the process of setting new Ukrainian school // Challenges and opportunities of scientific thought development : collection of scientific articles. GPG Publishing Group, Pretoria, South Africa, 2017. Pp. 151-156. 
13. Matviienko Olena. Social and educational causes of deformation in the moral development of children of primary school age // Economics, management, law: problems of establishing and transformation: Collection of scientific articles. Psychology. Pedagogy and Education. - Al-Ghurair Printing \& Publishing LLC, Dubai, UAE, 2016. Pp. 382-386.

14. Matviienko Olena. Theoretical Basics of Preparation of Teachers to Pedagogical Interaction with Children of Various Age. Intellectual Archive. 2014. Volume 5. No. 5 (September). Toronto : Shiny Word Corp., Canada. PP. 105-117.

15. Matviienko Olena. Theoretical bases of teacher's professional formation // Economics, management, law: socio-economical aspects of development: Collection of scientific articles. Volum 2. Psychology. Pedagogy and Education. - Edizioni Magi. Roma, Italy. 2016. Pp. 237-239.

16. Matviienko O., Scyhmeystryh O. Multicultural upbringing of primary school children in the conditions of Ukraine's eurointegration // World scientific extent : Collection of scientific articles. - Agenda Publishing House, Coventry, United Kingdom, 2017. Pp. 410-415.

17. McHoskey John \& Worzel William \& Szyarto Christopher. Machiavellianism and Psychopathy. Journal of personality and social psychology. 1998; 74. 192-210.

18. McHoskey John. Machiavellianism and personality dysfunction. Personality and Individual Differences. 2001. No 31, pp. 791-798.

19. Moss P., Tilly C. Soft' skills and race: An investigation of black men's employment problems. Work and Occupations. 1996. № 23 (3), pp. 252-276.

20. Muratori P., Lochman J. E, Manfredi A., Milone A., Nocentini A., Pisano S., Masi G. Callous unemotional traits in children with disruptive behavior disorder: Predictors of developmental trajectories and adolescent outcomes. Psychiatry Res. 2016 Feb 28; 236:35-41.

21. Ochsner Kevin \& Gross James. The Cognitive Control of Emotion. Trends in cognitive sciences. 2005. No 9, pp. 242-249.

22. Overgaauw S., Rieffe C., Broekhof E., Crone E. A and Güroglu B. Assessing Empathy across Childhood and Adolescence: Validation of the Empathy Questionnaire for Children and Adolescents (EmQue-CA). Front. Psychol. 2017; 8:870. doi: 10.3389/fpsyg.2017.00870

23. Parkinson, Brian. Emotions are social."British journal of psychology. 1996. No. 4 pp. $663-683$.

24. Pessoa, Luiz. Cognitive Control and Emotional Processing. 2017.

25. Petko L.V. Derzhavnyi standart pochatkovoi osvity u rakursi formuvannia sotsialnoi aktyvnosti dytyny [The State Standard for elementary education in the views of social activity formation in a child]. Naukovi zapysky Berdianskoho derzhavnoho ped. un-tu. Seriia: Pedahohika: zb. nauk. pr. Berdiansk : BDPU, 2018. Issue 1. P. 92-97. doi 10.31494/2412-9208-2018-1-1-92-97

26. Pet'ko L.V. Hurtok «Mandrivnyky» ta formuvannia sotsialnoi aktyvnosti molodshykh shkoliariv [The circle "Travellers" and forming social activities in primary school children]. Pedahohichnyi almanakh: zb. nauk. pr. ; redkol. V.V.Kuzmenko ta in. - Kherson: KVNZ «Khersonska akademiia neperervnoi osvity», 2018. Issue 37. P. 34-39.

URI : http://enpuir.npu.edu.ua/handle/123456789/18687

27. Pet'ko Lyudmila. Environmental approach in the formation of social activity in primary school children // Problems of modern science: Collection of scientific articles. - Fadette editions, Namur, Belgium, 2018. PP. 190-194. 
28. Pet'ko L.V. Teaching methods and the formation of professionally oriented foreign language learning environment in conditions of university. Intellectual Archive. 2016. Volume 5. No. 4 (July/August). Toronto : Shiny Word Corp., Canada. Pp. 73-87.

29. Pokhrel P., Herzog T. A., Black D. S., Zaman, A., Riggs N. R., \& Sussman S. Adolescent neurocognitive development, self-regulation, and school-based drug use prevention. Prevention science : the official journal of the Society for Prevention Research. 2013. No. 14(3), 218-228.

30. Ryan R. M., Deci E. L. On happiness and human potentials: a review of research on hedonic and eudaimonic well- being Annu. Rev. Psychol. 2001.52 (1), pp. 141-166.

31. Rubin Kenneth H. Egocentrism in Childhood: A Unitary Construct? Child Development, vol. 44, no. 1, 1973, pp. 102-110.

32. Schore A. N. Affect dysregulation and disorders of the self (Norton Series on interpersonal neurobiology). WW Norton \& Company. 2003.

33. Sharon L. Foster and Wendy L. Ritchey Issues in the assessment of social competence in children. Journal of Applied Behavior Analysis. 1979 Winter; 12(4): 625-638.

34. Tkach B. M. Neuropsychological correction of non-normative aggression in children and adolescents. A Young Scientist. 2016. No. 1, pp. 239-245.

35. Wentzel K. R. Relations between social competence and academic achievement in early adolescence. Child Development. 1991;62(5):1066-1078.

\section{Translation of the Title and Abstract to the Author's Language}

\section{УДК 37.013 .8}

Матвієнко Олена, Губарєва Дар'я. Діагностика рівня соціальної компетентності в учнів молодшого шкільного віку.

Розглянуто проблематику соціальної компетентності. Запропоновано структуру соціальної компетентності та модель іiї виміру. Наголошено, що першою фазою формування основ соціальної компетентності дитини є iї сім’я. Однак, пізніше стає її освітній простір, що стає важливим для вимірювання рівня даної компетентності під час освітнього процесу.

Презентовано діагностику рівня соціальної компетентності в учнів 2-х класів (7-8 років), де у формувальному експерименті прийняли участь 402 молодших школяра та 16 вчителів. На базі діагностики Assessment of Social Competence (ASC): A scale of social competence functions (1985), адаптованої під вітчизняні цінності та вік молодшого школяра, було виявлено перевищення початкового та середнього рівнів соціальної компетентності 3 найбільш розвинутою функцією турботливого мислення. Що $\epsilon$ закономірним для даної вікової групи; своєю чергою, розуміння соціальної реальності та зупинка прояву егоцентризму показали найбільші показники на початковому рівні соціальної компетентності, що вказує на один 3 напрямів роботи при формуванні основ даної компетентності та вказує на цілеспрямований процес виховання.

Ключові слова: соціальна компетентність, соціальна гнучкість, молодший школяр, функції соціальної компетентності, компоненти соціальної компетентності. 